OPEN ACCESS

Edited by:

Urs Feller,

University of Bern, Switzerland

Reviewed by:

Shabir Hussain Wani,

Michigan State University,

United States

Bingcheng Xu,

Institute of Soil and Water

Conservation (CAS), China

Abbu Zaid contributed to the review

of Shabir Hussain Wani

*Correspondence:

Xiliang Li

lixiliang0824@126.com

Specialty section:

This article was submitted to Agroecology and Land Use Systems,

a section of the journal

Frontiers in Plant Science

Received: 06 October 2017

Accepted: 21 February 2018

Published: 12 March 2018

Citation:

Liu Z, Baoyin T, Duan J, Yang G, Sun $J$ and Li X (2018) Nutrient Characteristics in Relation to Plant Size of a Perennial Grass Under Grazing Exclusion in Degraded Grassland. Front. Plant Sci. 9:295. doi: 10.3389/fpls.2018.00295

\section{Nutrient Characteristics in Relation to Plant Size of a Perennial Grass Under Grazing Exclusion in Degraded Grassland}

\author{
Zhiying Liu', Taogetao Baoyin', Junjie Duan², Guofeng Yang ${ }^{3}$, Juan Sun ${ }^{4}$ and \\ Xiliang $L i^{2,5 *}$ \\ ${ }^{1}$ Key Laboratory of Grassland Ecology, School of Ecology and Environment, Inner Mongolia University, Hohhot, China, \\ ${ }^{2}$ National Forage Improvement Center, Institute of Grassland Research, Chinese Academy of Agricultural Sciences, Hohhot, \\ China, ${ }^{3}$ School of Life Sciences, Qingdao Agricultural University, Qingdao, China, ${ }^{4}$ School of Animal Science and \\ Technology, Qingdao Agricultural University, Qingdao, China, ${ }^{5}$ Key Laboratory of Grassland Ecology and Restoration of the \\ Ministry of Agriculture, Hohhot, China
}

Identifying the linkages between nutrient properties and plant size is important for reducing uncertainty in understanding the mechanisms of plant phenotypic plasticity. Although the positive effects of grazing exclusion on plant morphological plasticity has been well documented, surprisingly little is known about the relationship of nutrient strategies with plant shoot size after long-term grazing exclusion. We experimentally investigated the impacts of grazing exclusion over time $(0,9,15$, and 35 years) on the relationships of nutrient traits (nutrient concentration, allocation, and stoichiometry) of with morphological plasticity in Leymus chinensis, which is a dominant species in grasslands of Inner Mongolia, China. Our results showed that there was a significantly negative correlation between the degrees of plasticity and stability of various morphological traits. Increases in plant size by $126.41,164.17$, and $247.47 \%$ were observed with the increase of grazing exclusion time of 9, 15, and 35 years, respectively. Plant size was negatively correlated with nitrogen $(N)$ and phosphorus $(P)$ concentrations, but was positively correlated with carbon (C) concentration. Biomass partitioning and leaf to stem ratios of nutrient concentrations contributed more than 95\% of the changes in N, P, and C allocation in L. chinensis leaves and stems induced by grazing exclusions. Nine years' grazing exclusion rapidly changed the nutrient concentrations (averaged by $-34.84 \%$ ), leaf to stem nutrient allocations (averaged by $-86.75 \%$ ), and ecological stoichiometry (averaged by $+46.54 \%$ ) compared to freegrazing, whereas there was no significant trend of these nutrient traits across the 9 , 15 , and 35 years' grazing exclusion in L. chinensis individuals. Our findings suggest that with the increase of the duration of the grazing exclusion, time effects on plant performances gradually weakened both in plant morphological plasticity and nutrient properties. There is a significant negative effect between plant sizes and nutrient traits under long-term grazing exclusion.

Keywords: phenotypic plasticity, livestock grazing, Leymus chinensis, plant nutrient strategy, functional traits 


\section{INTRODUCTION}

Phenotypic plasticity is defined as the ability of a single plant genotype to produce different phenotypes (morphology, phenology, or physiology) under various biotic and abiotic disturbances, including herbivore grazing, bio-invasion, elevated $\mathrm{CO}_{2}$, warming, and drought (Nicotra et al., 2010; Dostál et al., 2016; Wang D. et al., 2017). The potential role of phenotypic plasticity on the change of ecosystem function has attracted the interest of grassland ecologists. Furthermore, it provides a new theoretical perspective for understanding how plant functional traits mediate the restoration of grassland ecosystem performance under grazing exclusion (Li et al., 2016a; Wang D. et al., 2017).

In grazing ecosystem, the grazing of large herbivores directly influences the phenotypic characteristics of grassland species by impacting leaf photosynthesis, respiration, and plant development; it can also influence indirectly grassland species by changing the soil micro-environment (Ren et al., 2017; Abdalla et al., 2018). It has long been recognized that plant individuals will become dwarfed in response to overgrazing, whereas plant size will return to normal after exclusion from grazing over a multi-year period (Armitage et al., 2012). Recent results from a long-term grassland trial indicated sheep grazing caused the decline of aboveground biomass of Leymus chinensis, primarily through a 'bottom-up' effect due to the asymmetrical response of different plant functional traits with the variations in individual plant size (Li et al., 2015a). During grazing exclusion, however, the patterns of the phenotypic variations of plant species in a long-term study in a degraded pasture are largely unknown.

Over the past few decades, grazing exclusions have become a primary management practice for the restoration of degraded pastures in semi-arid regions worldwide (Han et al., 2008; Jing et al., 2014). Plant-soil interactions play an important role in the maintenance of both plant community composition and soil properties in the transition from degraded grasslands to restored grasslands by grazing exclusion (Laliberté et al., 2012; Odriozola et al., 2017). In general, grazing exclusion can enhance ecosystem stability and productivity in the initial years of the exclusion. (Deng et al., 2017). However, some studies have demonstrated that long-term grazing exclusion could exert a negative influence on species renewal and productivity (Silcock and Fensham, 2013). For example, Jing et al. (2014) reported that the productivity and biodiversity were higher in the mid- and transitional stages of succession, but decreased with increasing restoration time in a semiarid grassland.

Plasticity in plant nutrient traits, including the content, resorption, stoichiometry, and allocation of nutrients, is predicted to play a key role in regulating the morphological plasticity, indirectly affecting the carbon (C) cycle and ecosystem stability (Lü et al., 2012a; Heyburn et al., 2017). The plasticity in the nutrient resorption efficiency and proficiency is an important nutrient strategy for plants subjected to grazing (da Silveira Pontes et al., 2010). In a semi-arid grassland, Lü et al. (2015) found that the dominate grass species displayed decreasing nutrient resorption with the duration of grazing exclusion for nitrogen $(\mathrm{N})$ and phosphorus $(\mathrm{P})$. There is abundant evidence that $\mathrm{C}: \mathrm{N}: \mathrm{P}$ stoichiometry in plant tissues are generally associated with plant growth strategies, which strongly influence the capacity for adaptation to grazing disturbance (Velthuis et al., 2017; Yang et al., 2017). Moreover, nutrient allocation is regulated by grazing primarily through the changes in biomass partitioning and nutrient concentrations (Li et al., 2016b). Grazing-induced shifts in nutrient allocation patterns among different tissues are indirectly influenced by the availability of soil resources (Bai et al., 2012; Zheng et al., 2012). However, there is a lack of long-term investigations into the effects of grazing exclusion on the relationship between plant morphological plasticity and the nutrient strategies of grassland plants.

Native pastures in typical steppe regions cover the largest area in the eastern Eurasian temperate grasslands at the northern boundary of China (Schönbach et al., 2009). In these pastures, the dominant grass species is L. chinensis, which grows rapidly and has a high tolerance to arid conditions. This perennial rhizomatous grass is also very palatable to grazing animals and has a high forage value (Ma et al., 2014; Ren et al., 2014). L. chinensis is considered one of the most promising grass species for grassland rehabilitation and restoration in arid regions of northern China (Liu and Han, 2008; Huang et al., 2015).

Therefore, in this study, L. chinensis (the dominant grassland species) was chosen as a model plant for exploring ecological processes. We examined the effects of grazing exclusion on morphological plasticity, nutrient concentration, accumulation, allocation, and ecological stoichiometry of L. chinensis along a time series in a degraded pasture located in Xilinhot, Inner Mongolia, China. Specifically, we addressed the following four questions: (i) How do morphological plasticity and biomass allocation change across a grazing exclusion chronosequence? (ii) How does grazing exclusion influence the relationships between the size of L. chinensis and the concentrations of carbon $(\mathrm{C})$, nitrogen $(\mathrm{N})$, and phosphorous $(\mathrm{P})$ in leaves and stems? (iii) How does grazing exclusion affect $\mathrm{C}, \mathrm{N}$, and $\mathrm{P}$ allocation strategies in $L$. chinensis in plants of varying sizes? (iv) How does grazing exclusion affect the relationship between L. chinensis C:N:P stoichiometry and morphological plasticity?

\section{MATERIALS AND METHODS}

\section{Study Area}

This study was conducted at the Xilingol Grassland Ecosystem Observation and Research Station $\left(43^{\circ} 38^{\prime} \mathrm{N}, 116^{\circ} 42^{\prime} \mathrm{E}\right)$ in the Xilin River catchment area of Inner Mongolia, China. The site has an altitude of $\sim 1,200 \mathrm{~m}$ a.s.l. and a semiarid continental climate characterized by a mean annual (1979-2013) precipitation of $328.54 \mathrm{~mm}$ and a mean annual temperature of $0.89^{\circ} \mathrm{C}$. Typically, maximum precipitation coincides with the months with the highest temperatures in June, July, and August. The growing season for perennial plants lasts for approximately 150 days from May to September. The vegetation in this region mainly consists of herbaceous plants, such as 
TABLE 1 | Mean (and SD) of individual plant size of Leymus chinensis in response to grazing exclusion of differing lengths in a degraded pasture.

\begin{tabular}{|c|c|c|c|c|c|c|c|c|c|}
\hline \multirow[t]{2}{*}{ Categories } & \multirow[t]{2}{*}{ Indexes } & \multicolumn{2}{|c|}{ CK } & \multicolumn{2}{|c|}{$9-y r$} & \multicolumn{2}{|c|}{$15-y r$} & \multicolumn{2}{|c|}{ 35-yr } \\
\hline & & Mean & $S D$ & Mean & $S D$ & Mean & $S D$ & Mean & $S D$ \\
\hline & Plant height $(\mathrm{cm})$ & $23.89^{d}$ & 3.30 & $54.09^{c}$ & 3.62 & $63.11^{b}$ & 4.37 & $83.01^{a}$ & 5.41 \\
\hline & Leaf number & $4.80^{\circ}$ & 0.56 & $5.60^{a}$ & 0.74 & $5.53^{a b}$ & 0.64 & $5.07 b^{c}$ & 0.70 \\
\hline Plant & Leaf length (cm) & $13.37^{d}$ & 1.14 & $22.23^{c}$ & 1.20 & $26.35^{b}$ & 1.88 & $32.24^{a}$ & 1.82 \\
\hline \multirow[t]{3}{*}{ properties } & Leaf width (mm) & $5.41^{d}$ & 0.65 & $7.39^{c}$ & 0.40 & $8.90^{\mathrm{a}}$ & 0.53 & $7.78^{b}$ & 0.48 \\
\hline & Stem length (mm) & $1.46^{\mathrm{c}}$ & 0.17 & $1.72^{b}$ & 0.07 & $2.02^{\mathrm{a}}$ & 0.17 & $2.02^{a}$ & 0.13 \\
\hline & Stem diameter (mm) & $10.92^{d}$ & 2.13 & $31.62^{\mathrm{C}}$ & 3.02 & $37.69^{b}$ & 4.36 & $49.59^{a}$ & 4.53 \\
\hline
\end{tabular}

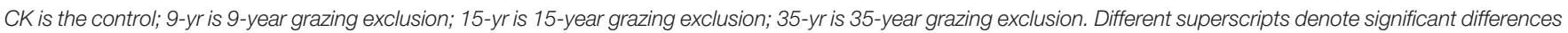
$(P<0.05)$.

L. chinensis, Stipa grandis, Achnatherum sibiricum, Agropyron cristatum, Caragana microphylla, and Cleistogenes squarrosa. The perennial rhizome grass L. chinensis dominates the typical steppe communities in Eurasian steppe regions, especially in the Xilingol Grassland (He et al., 2009; Li et al., 2016a). The major soil types found in this grassland are calcic chestnuts and calcic
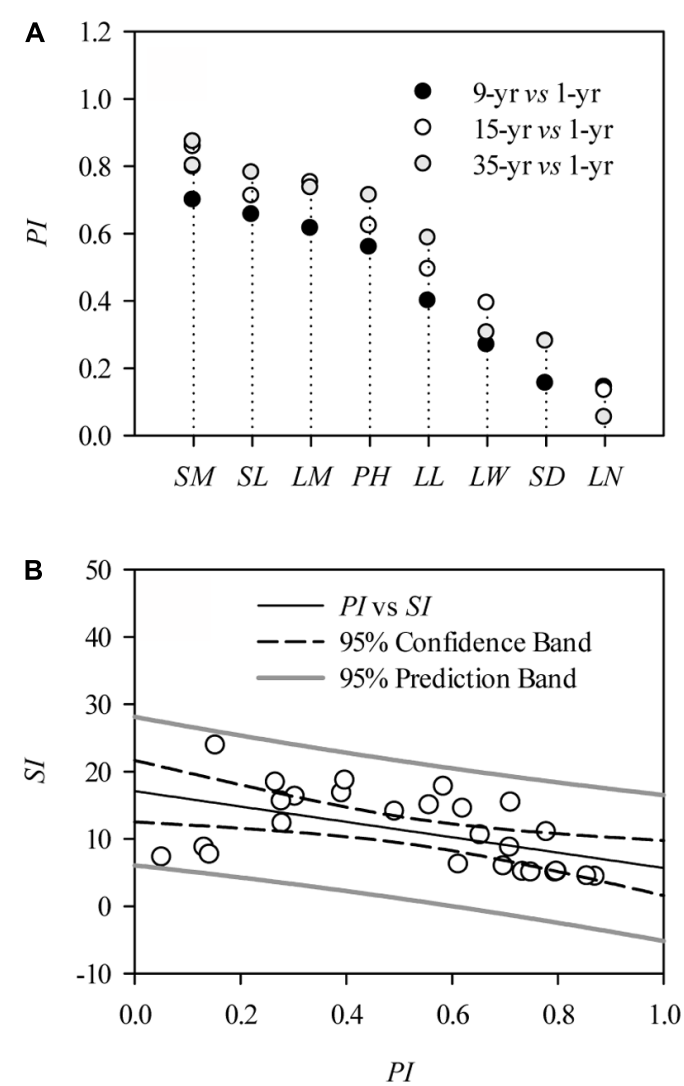

FIGURE 1 | Morphological plasticity of Leymus chinensis in response to grazing exclusions. (A) Plasticity indexes $(P /)$ of morphological traits, including: $S M$, stem mass; $A M$, aboveground mass; $S L$, stem length; $L M$, leaf mass; $P H$, plant height; $L L$, leaf length; $L W$, leaf width; $S D$, stem diameter; and $L N$, leaf number. (B) Correlation between $P I$ and stability indexes $(S I)$ of plant morphological traits of $L$. chinensis in response to grazing exclusion; the relation between them is fitted by a Pearson correlation $(r=-0.52, P<0.01)$. chernozems. The content of calcium carbonate accounts for $0.80 \%$ of the total soil in topsoil layers (He et al., 2009).

\section{Site Description and Experimental Design}

Three vegetation restoration treatments and one free-grazing treatment in L. chinensis grassland were conducted in this study. The long-term restoration treatments were excluded from grazing or were enclosed by fencing, with each plot closed off in different years. The chronosequence of grazing exclusion was represented by three nearby plots, which included grazing exclosures dating from 2005, 1999, and 1979. Therefore, the duration of grazing exclusion of the four sites was $0,9,15$, and 35 years to the sampling year of 2014. Each plot ranged in size from 5 to 40 ha. Like most chronosequence studies, the sites were subjected to pseudo-replication and 'space-fortime substitution' approaches to overcome the obstacle of studying up to several decades of grazing exclusion (Conant and Paustian, 2002; Lü et al., 2015; Eby et al., 2017). The four experimental plots, the three restored sites and one grazed contr ol site, were contiguously distributed on the same upper basalt platform; they appeared to be topographically and floristically similar and generally experienced low frequency and severity of disturbance, thus grazing exclusion was identified as the only important factor of change across the plots.

The grazing plot (control plot) had been grazed by sheep and goats year-round for more than 50 years at a stocking rate of approximately 3 sheep per hectare. This was significantly higher than the local stocking rates of 1.5 sheep per hectare needed to maintain grass-livestock balance, as recommended by the local government. Livestock consumed an estimated more than 75\% of the aboveground biomass each year and the vegetation cover during our fieldwork was 25 30\%. The living and litter biomass of the degraded community were only in approximately 50 and $5 \mathrm{~g} \cdot \mathrm{m}^{-2}$, respectively. Though the palatable grass of $L$. chinensis generally dominated in native community, it only accounted for approximately $10 \%$ of the total aboveground productivity in the degraded grassland induced by livestock selective grazing (Li et al., 2015a). The grazing plot had a nutrient-poor topsoil characterized by total $\mathrm{N}$ of $1.8 \mathrm{~g} \mathrm{~kg}^{-1}$, total $\mathrm{P}$ of $0.3 \mathrm{~g} \mathrm{~kg}^{-1}$, inorganic $\mathrm{N}$ of $3.6 \mathrm{mg} \mathrm{kg}^{-1}$ and available $\mathrm{P}$ of $5.0 \mathrm{mg} \mathrm{kg}^{-1}$ 

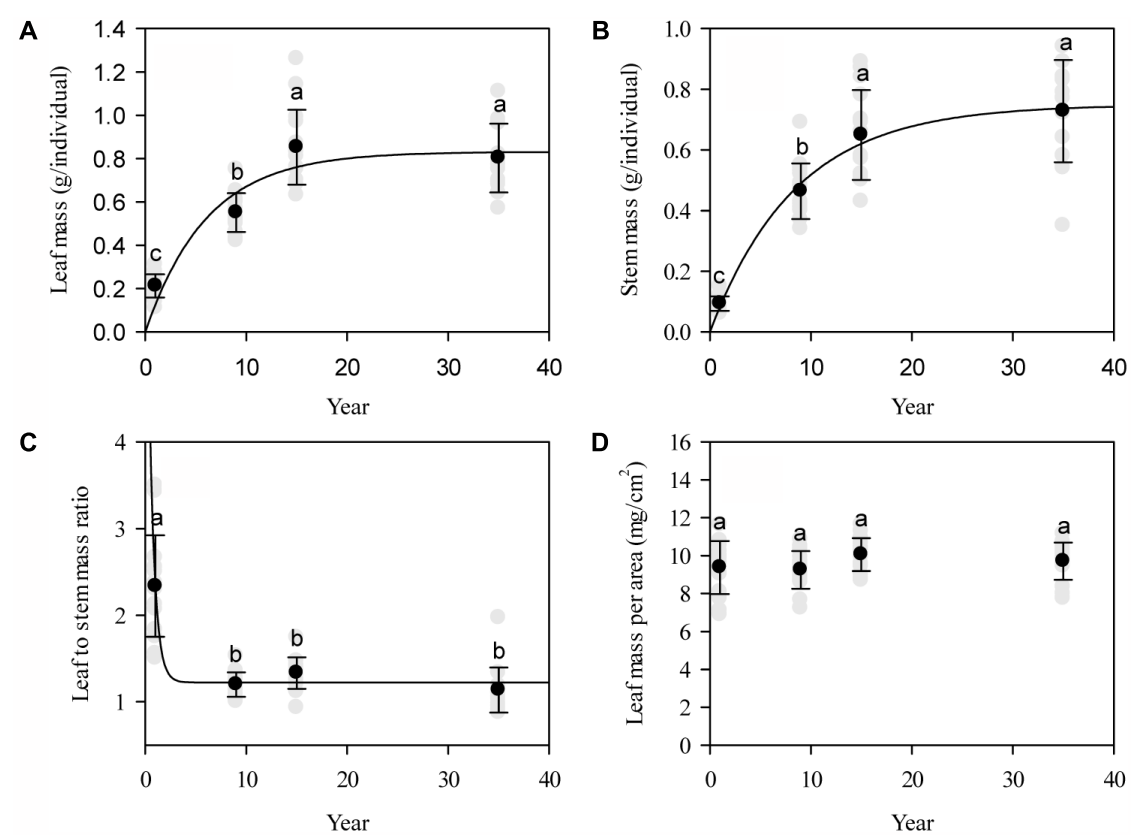

FIGURE 2 | Patterns of individual biomass accumulation (A) and allocation (mean \pm SD) in leaves and stems (B-D) of Leymus chinensis following grazing exclusion in a degraded pasture. The patterns of leaf mass $(r=0.85, P<0.001)$ and stem mass $(r=0.90, P<0.001)$ are fitted by an exponential rise to the maximum, whereas the leaf to stem mass ratio $(r=-0.82, P<0.001)$ displays an exponential decay. Different superscripts denote significant differences $(P<0.05)$.

(Lü et al., 2015). The topsoil had an organic matter content of $2.0 \%$.

Grazing exclusion plots (enclosed 9, 15, and 35 years) were located adjacent to the grazing plots, ranging in aboveground biomass from 140 to $160 \mathrm{~g} \mathrm{~m}^{-2}$. According to our community monitoring data, the relative contribution of L. chinensis to total above-ground biomass obviously increased from about $10 \%$ (grazing plots) to $60 \%$ (1979 enclosure) with the duration of grazing exclusion in the chronosequence. The bulk density $\left(1.2 \mathrm{~g} \mathrm{~cm}^{-3}\right)$ of topsoil was always significantly lower than the free-grazing plot. However, the topsoil nutrients in 9, 15, and 35 years' plots were found in relatively high levels (total $\mathrm{N}$ of $2.2 \sim 2.6 \mathrm{~g} \mathrm{~kg}^{-1}$ and total $\mathrm{P}$ of $0.3 \mathrm{~g} \mathrm{~kg}^{-1}$, inorganic $\mathrm{N}$ of $5.0 \sim 9.2 \mathrm{mg} \mathrm{kg}^{-1}$ and available $\mathrm{P}$ of $3.1 \sim 5.4 \mathrm{mg} \mathrm{kg}^{-1}$ ) (Lü et al., 2015). The humus layer thickness of was in the range of $30 \sim 45 \mathrm{~cm}$, and had an organic matter content of $2.2 \sim 2.5 \%$.

In early spring in 2014, we established three $15 \times 15 \mathrm{~m}$ reduplicated sub-plots representative of the vegetation present within each plot of distinct grazing exclusion history. Five $1 \mathrm{~m} \times 1 \mathrm{~m}$ quadrats were established in each sub-plot for sampling, with a total of 15 quadrats in each treatment. In each grazing quadrat, a temporary movable exclosure cage was set up at each sampling point prior to grazing and before the growing season began in the early spring of 2014. The quadrats were at least $5 \mathrm{~m}$ apart and the physiographic conditions within the quadrats were similar.

\section{Sampling and Measurement}

Field sampling was conducted from August 15th to 18th, 2014, which corresponds with the annual peak standing biomass.
Five L. chinensis individuals were selected randomly in each $1 \mathrm{~m} \times 1 \mathrm{~m}$ quadrat. Phenotypic functional traits (plant height, leaf number, leaf length, leaf width, stem length, stem diameter, and biomass accumulation) of each L. chinensis individual were measured in the laboratory after the entire aboveground portion was completely clipped in the field. Leaf width and stem diameter were measured using vernier calipers (precision $=0.01 \mathrm{~mm}$ ). After the measurement of phenotypic traits, the leaves and stems were packaged in individual paper bags, and all plant samples were oven-dried at $65^{\circ} \mathrm{C}$ for at least $48 \mathrm{~h}$. Stem, leaf, and total biomass of $L$. chinensis were measured after drying.

The leaves and stems of the L. chinensis individuals in each quadrat were combined, pulverized using a mechanical mill (Retsch MM 400, Retsch GmbH \& Co KG, Haan, Germany), and passed through a 40-mesh sieve. The total concentration of $\mathrm{C}$ in leaves and stems was determined using the $\mathrm{H}_{2} \mathrm{SO}_{4}-\mathrm{K}_{2} \mathrm{Cr}_{2} \mathrm{O}_{7}$ oxidation method. Subsamples were digested in $\mathrm{H}_{2} \mathrm{SO}_{4}-\mathrm{H}_{2} \mathrm{O}_{2}$ (Bennett et al., 2003). The total concentration of $\mathrm{N}$ was analyzed using an Alpkem autoanalyzer (Kjektec System 1026 Distilling Unit, Sweden), and the total concentration of $\mathrm{P}$ was measured colorimetrically at $880 \mathrm{~nm}$ after reaction with molybdenum blue. All stoichiometric ratios of $\mathrm{C}: \mathrm{N}: \mathrm{P}$ were reported as mass ratios (Lü et al., 2012b).

\section{Statistical Analysis}

The mean of each of the plant traits was calculated from measurements taken from all the L. chinensis individuals in a single quadrant. A principal component analysis (PCA) was performed to determine relationships among plant traits and the effect of grazing exclusion on these traits (Fort et al., 2015; 

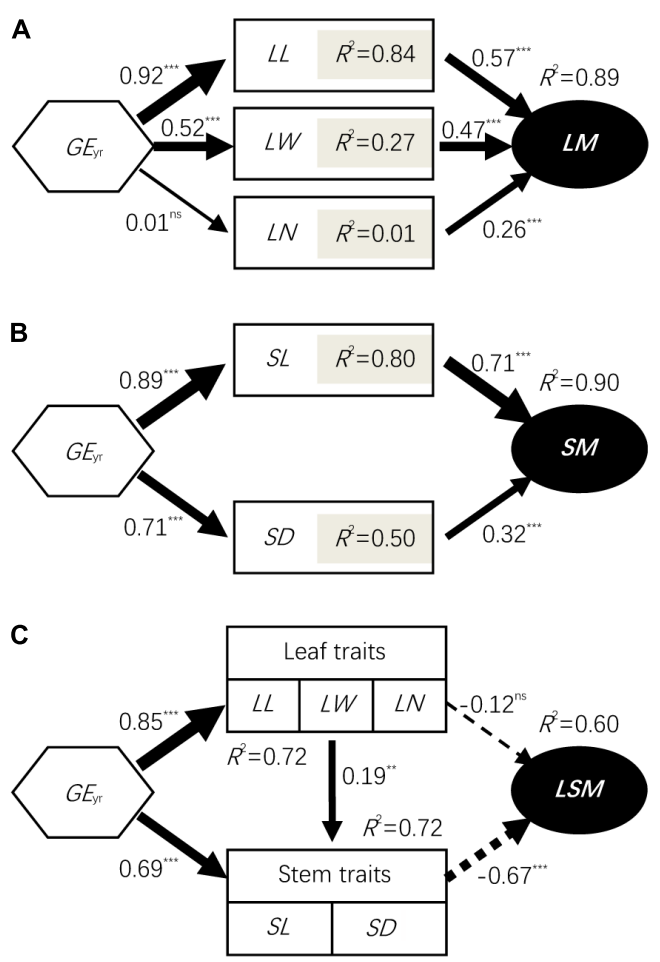

FIGURE 3 | Structural equation modeling (SEM) results for the grazing exclusion effects on biomass accumulation $\mathbf{( A , B )}$ and allocation $\mathbf{( C )}$ at the individual level. Values associated with arrows represent standardized path coefficients. Solid and dashed arrows represent positive and negative paths, respectively, in a fitted SEM depicting the impact of variables on stem length decline. $R^{2}$ values associated with response variables indicate the proportion of variation explained by relationships with other variables. Symbols: *** represents $P<0.001$; **represents $P<0.01$; ns represents $P>0.05$. $L M$, leaf mass; $S M$, stem mass; $L S M$, leaf to stem mass ratio; $A M$, aboveground mass; $P H$, plant height; $L L$, leaf length; $L W$, leaf width; $S L$, stem length; $S D$, stem diameter; and $L N$, leaf number; $G E_{\mathrm{yr}}$, number of years of grazing exclusion.

Li et al., 2015b). For this analysis, we centered and normalized all variables with their standard deviations because they had different units. The importance of a trait in a given component is indicated by its relative loading on a component. Responses of functional traits of $L$. chinensis in the grazed and enclosed

TABLE 2 | Relationships of plant size (PC axis 1) with C, N, and P concentrations $\left(X_{\text {mass }}\right)$ and accumulations $\left(X_{\text {accumulation }}\right)$ in leaves, stems, and aboveground portions in Leymus chinensis individuals.

\begin{tabular}{|c|c|c|c|c|c|c|}
\hline \multirow[t]{2}{*}{ Indexes } & \multicolumn{2}{|c|}{ Leaf } & \multicolumn{2}{|c|}{ Stem } & \multicolumn{2}{|c|}{ Aboveground } \\
\hline & $r$ & $P$ & $r$ & $P$ & $r$ & $P$ \\
\hline$N_{\text {mass }}$ & -0.66 & $<0.01$ & -0.73 & $<0.01$ & -0.72 & $<0.01$ \\
\hline$P_{\text {mass }}$ & -0.42 & $<0.01$ & 0.32 & $<0.05$ & -0.27 & $<0.05$ \\
\hline $\mathrm{C}_{\text {mass }}$ & 0.45 & $<0.01$ & 0.63 & $<0.01$ & 0.56 & $<0.01$ \\
\hline $\mathrm{N}_{\text {accumulation }}$ & 0.59 & $<0.01$ & 0.71 & $<0.01$ & 0.63 & $<0.01$ \\
\hline$P_{\text {accumulation }}$ & 0.73 & $<0.01$ & 0.90 & $<0.01$ & 0.85 & $<0.01$ \\
\hline $\mathrm{C}_{\text {accumulation }}$ & 0.66 & $<0.01$ & 0.78 & $<0.01$ & 0.73 & $<0.01$ \\
\hline
\end{tabular}

grassland plots were analyzed using the plasticity index $(P I)$ (Olmo et al., 2014; Li et al., 2015a):

$$
P I=\frac{F E-F G}{F E}
$$

where $F E$ is the value of functional traits in habitats of grazing exclusion plots, and $F G$ is the value of functional traits in long-term grazed habitats.

The degrees of stability of L. chinensis traits in the sampled populations were analyzed by a stability index (SI), which was represented by the reciprocal of the coefficient of variation $(\mathrm{CV})$ :

$$
S I=\frac{S D}{F M}
$$

where $S D$ and $F M$ are the standard deviation and the average values of all the functional traits in the grazing exclusion plots, respectively.

The Kolmogorov-Smirnov test was used to test for normality among the average plant phenotypic traits and $\mathrm{C}, \mathrm{N}$, and $\mathrm{P}$ concentrations in L. chinensis leaves and stems. For each L. chinensis individual, $\mathrm{C}, \mathrm{N}$, and $\mathrm{P}$ content were calculated by multiplying the $\mathrm{C}, \mathrm{N}$, and $\mathrm{P}$ concentrations by the biomass of the corresponding tissues.

Structural equation modeling (SEM) was used to analyze hypotheses that may explain the pathways responsible for the indirect effects of grazing exclusions on biomass accumulation and allocation, and $\mathrm{C}, \mathrm{N}$, and $\mathrm{P}$ accumulation of individual L. chinensis plants (Byrne, 2013; Li et al., 2016b). Structural equation models were developed based on hypothesized relationships between variables and tests of preliminary models. Co-varying factors with non-significant regression weights within the SEMs were not included. The final SEMs were applied to each of the L. chinensis functional trait indices. Occasionally, it was necessary to alter the relationship between a measured L. chinensis functional trait and the rest of the model (Li et al., 2016b). The utility of each functional trait index within the SEM was compared based on a number of measures. These include the power of the particular model to explain the variation $\left(r^{2}\right)$, measures of model significance and fit ( $\chi^{2}$ and AIC), and the significance of the functional trait variables within the model (significance of regression weights) (Li et al., 2016a).

Significant differences in plant traits between various treatments were evaluated using one-way analysis of variance (ANOVA). Pearson's correlation method was selected to test the relationships between two variables. All statistical analyses were performed using SPSS 19.0 statistical software (SPSS, Inc., Chicago, IL, United States), with $P<0.05$ set as the level of significance. Structural equation modeling analysis was performed using AMOS 20.0 software (IBM, SPSS, Armonk, NY, United States).

\section{RESULTS}

\section{Morphological Plasticity}

At the individual level, the morphological traits, including leaf and stem traits, were significantly positively affected by 9,15 , 

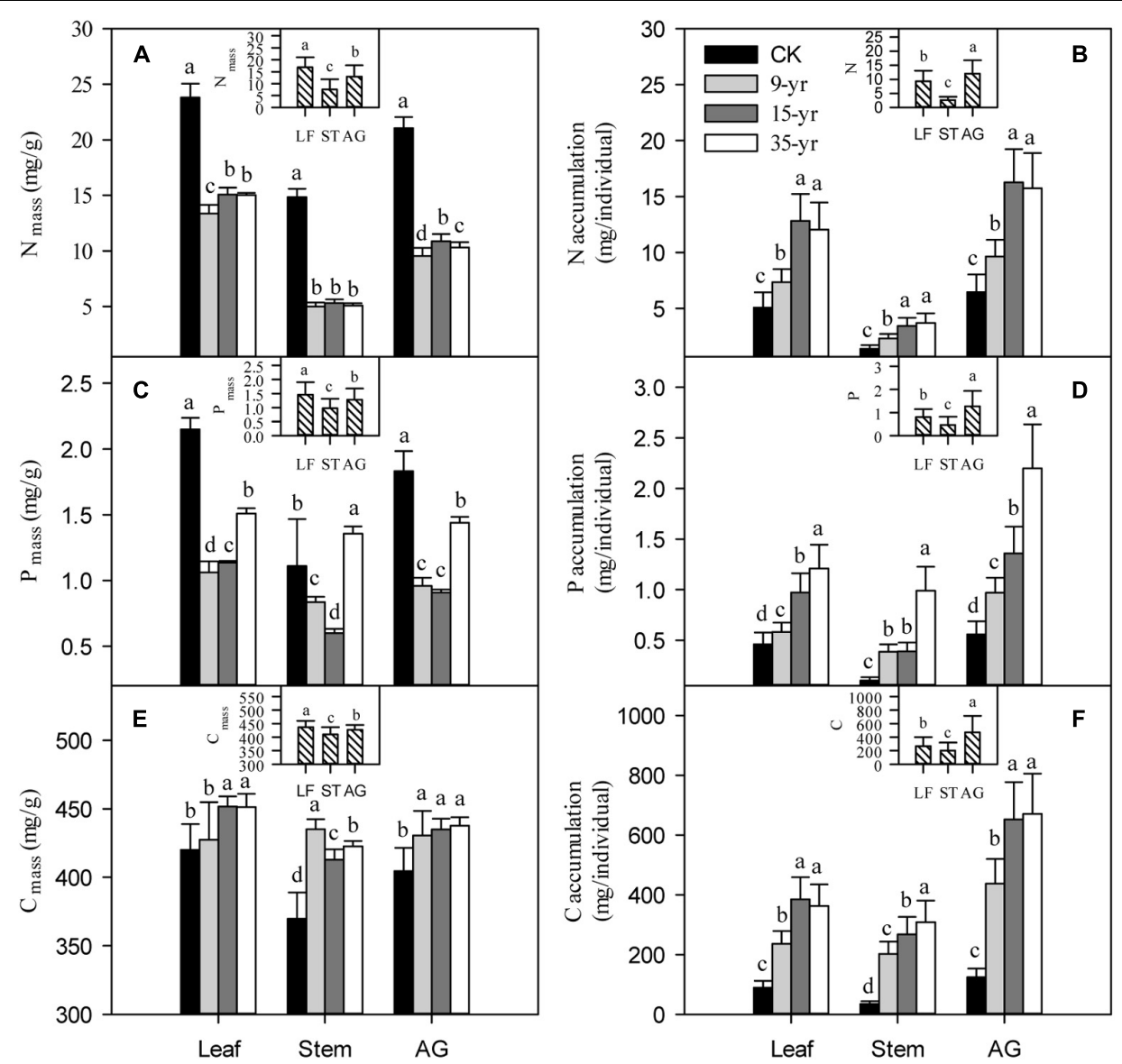

FIGURE 4 | Effects of grazing exclusion on C, N, and P concentrations (A,C,E, respectively) and accumulations (B,D,F, respectively) in leaves, stems, and the aboveground portions of Leymus chinensis individuals following grazing exclusion (mean \pm SD). CK is open grazing; 9-yr is 9-year grazing exclusion; 15-yr is 15-year grazing exclusion; 35-yr is 35-year grazing exclusion; $A G$ is aboveground portion; $L F$ is leaf; $S T$ is stem. Different superscripts denote significant differences $(P<0.05)$.

and 35 years' grazing exclusion $(P<0.05$; Table 1). However, some $L$. chinensis traits, such as leaf number, leaf width, and stem diameter, in long-term grazing exclusions (the plot from 1979) were slightly lower compared to those in the plot established in 1999 (Table 1). Ranking of the highly varied plasticity indexes of morphological traits indicated that the morphological traits of $L$. chinensis can be distinguished into sensitive traits (i.e., leaf length) and sluggish traits (i.e., stem diameter) in response to grazing exclusion over time (Figure 1A). There was a significantly negative correlation between plasticity and stability indexes across grazing exclusions over time $(P<0.01$; Figure 1B).

Affected by grazing exclusion, leaf mass per individual significantly increased $(P<0.01$; Figure $2 \mathbf{A})$. The variation of leaf mass accumulation per $L$. chinensis individual was primarily driven by the variation of leaf length, leaf width, and leaf number $(P<0.01$; Figure 3A). Similarly, stem mass accumulation was highly correlated with the increase of grazing exclusion time, with an initial exponential increase $(P<0.01$; Figure 2B). The variation of stem mass per $L$. chinensis individual was caused by the variation of stem length and stem diameter $(P<0.01$; Figure 3B). The leaf-to-stem biomass ratio was negatively
TABLE 3 | Relations between C, N, and P concentrations and accumulations in leaves, stems, and aboveground portions in Leymus chinensis individuals.

\begin{tabular}{|c|c|c|c|c|c|c|}
\hline \multirow[t]{2}{*}{ Elements } & \multicolumn{2}{|c|}{ Leaf } & \multicolumn{2}{|c|}{ Stem } & \multicolumn{2}{|c|}{ Aboveground } \\
\hline & $r$ & $\boldsymbol{P}$ & $r$ & $P$ & $r$ & $P$ \\
\hline $\mathrm{N}$ & -0.54 & $<0.01$ & -0.68 & $<0.01$ & -0.61 & $<0.01$ \\
\hline $\mathrm{P}$ & -0.31 & $<0.05$ & 0.44 & $<0.01$ & -0.17 & $>0.05$ \\
\hline C & 0.58 & $<0.01$ & 0.67 & $<0.01$ & 0.66 & $<0.01$ \\
\hline
\end{tabular}

correlated with the increase of grazing exclusion time $(P<0.01$; Figures 2C,D). We detected that the change in stem traits was the major driving factor for the decreased leaf-to-stem allocation induced by grazing exclusion $(P<0.01$; Figure $3 \mathrm{C})$.

\section{Tradeoff Between Nutrient Concentration and Accumulation}

Plant size was negatively correlated with $\mathrm{N}$ and $\mathrm{P}$ concentrations, but it was positively correlated with $\mathrm{C}$ concentration. However, with the increase of plant size, N, P, and C accumulations 

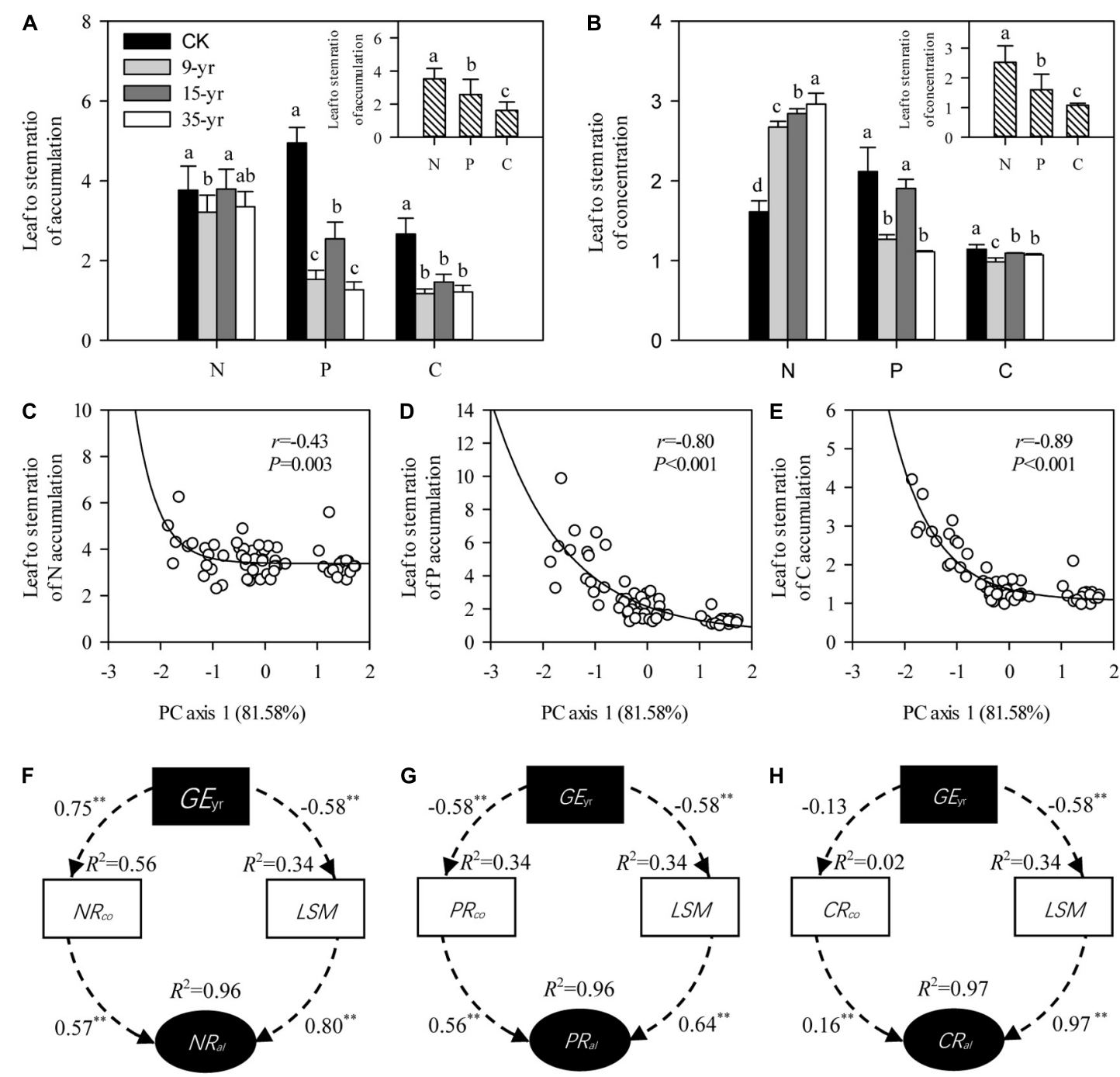

FIGURE 5 | Effects of grazing exclusion on the N, P, C allocations in leaves and stems of Leymus chinensis individuals (mean \pm SD). (A) Leaf to stem ratios of N, P, and $\mathrm{C}$ accumulation in response to grazing exclusions. (B) Leaf to stem ratios of N, P, and C concentration in response to grazing exclusions. (C-E) Relationships of plant traits (PC axis 1) with leaf to stem ratios of N, P, and C accumulation, respectively. (F-H) Pathways of the changes in leaf to stem ratios of $\mathrm{N}$, P, and $\mathrm{C}$ accumulation induced by grazing exclusions, respectively. Values associated with arrows represent standardized path coefficients. $R^{2}$ values associated with response variables indicate the proportion of variation explained by relationships with other variables. Symbols: $* * *$ represents $P<0.001$. $X R_{\mathrm{co}}$ is leaf to stem ratios of $\mathrm{N}, \mathrm{P}$, and $\mathrm{C}$ concentrations; $X R_{\mathrm{al}}$ is leaf to stem ratios of $\mathrm{N}, \mathrm{P}$, and $\mathrm{C}$ accumulations; CK is open grazing; 9-yr is 9-year grazing exclusion; 15-yr is 15-year grazing exclusion; 35-yr is 35-year grazing exclusion. Different superscripts denote significant differences $(P<0.05)$.

increased linearly (Table $2 ; P<0.05$ ). We found that there was a rapid decrease of $\mathrm{N}$ and $\mathrm{P}$ concentration in leaves, stems, and the aboveground portion of $L$. chinensis individuals after grazing was excluded from the degraded pasture $(P<0.05)$. However, only slight changes in $\mathrm{N}$ and $\mathrm{P}$ concentration were found across the exclusion pastures established in 2005, 1999, and 1979 (Figures 4A,C). The accumulation of $\mathrm{N}$ and $\mathrm{P}$ in leaves, stems, and the aboveground portion gradually increased with the increase of grazing exclusion time $(P<0.05$; Figures 4B,D). In contrast, $\mathrm{C}$ concentrations rapidly increased shortly after grazing exclusion $(P<0.05)$, whereas it was not significantly affected by the increase of the grazing exclusion time $(P>0.05$; Figure 4E). The trend of $\mathrm{C}$ accumulation following grazing exclusion was similar to the trends observed for $\mathrm{N}$ and $\mathrm{P}$ $(P<0.05$; Figure 4F). In addition, we detected that the tradeoffs between the concentration and accumulation of $\mathrm{N}$ and $\mathrm{P}$ were similar (Table 3; $P<0.05$ ).

\section{Nutrient Allocation and Stoichiometry}

There was a rapid decrease in leaf to stem ratio of $\mathrm{P}$ and $\mathrm{C}$ accumulation in $L$. chinensis individuals after grazing exclusion $(P<0.05$; Figure 5A), but no distinct trend was found in these ratios across the chronosequence (Figure 5A). In general, leaf to stem ratios of $\mathrm{N}, \mathrm{P}$, and $\mathrm{C}$ accumulation were negatively correlated with plant size variation induced by grazing exclusion, as indicated by the model of exponential decay $(P<0.01$; 


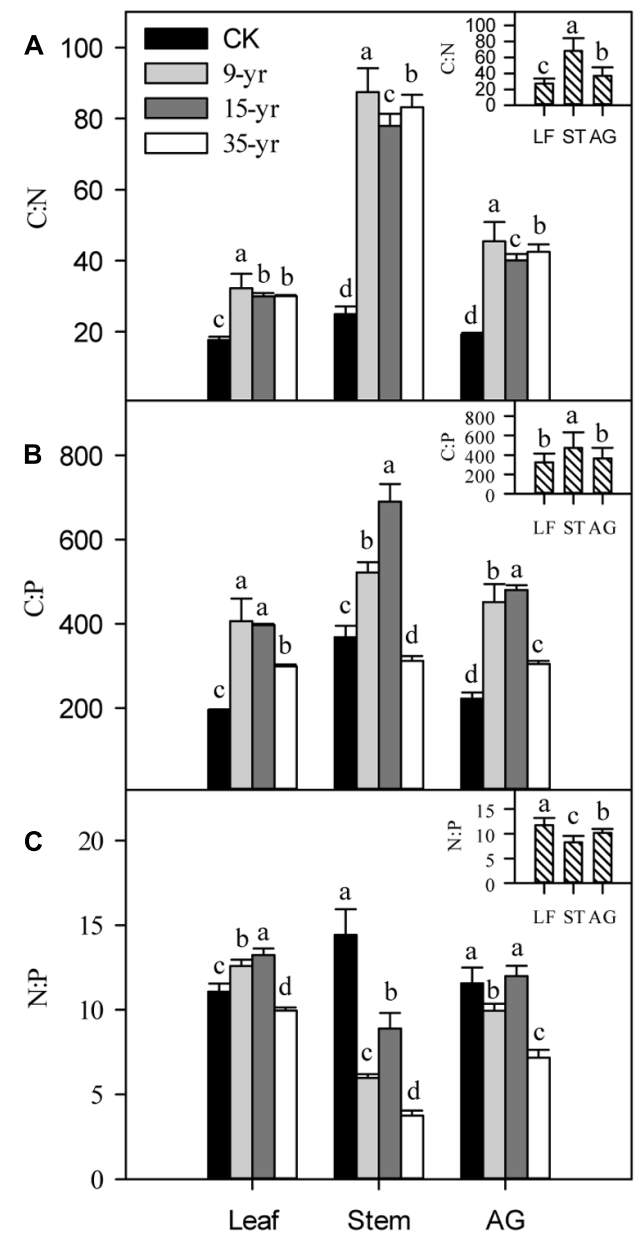

FIGURE 6 | Effects of grazing exclusion on C:N (A), C:P (B), and N:P (C) in leaves (LF), stems (ST), and the aboveground (AG) portions in Leymus chinensis individuals following grazing exclusion (mean $\pm \mathrm{SD}$ ). Different superscripts denote significant differences $(P<0.05)$.

Figures 5C-E). To explore the reason for changes in nutrient allocation, we further determined that there was an increase in the leaf to stem ratio of $\mathrm{N}$ concentration, but a decrease in $\mathrm{P}$ and $\mathrm{C}$ with a longer duration of grazing exclusion $(P<0.05$; Figure 5B). The pathway analysis fitted by SEM showed that the changes in $\mathrm{N}, \mathrm{P}$, and $\mathrm{C}$ allocation induced by grazing exclusions were in part due to leaf to stem ratios of biomass and nutrient concentration $(P<0.01$; Figures 5F-H).

Grazing exclusion rapidly increased the C:N and C:P in leaves, stems, and the aboveground portions of $L$. chinensis individuals $(P<0.05$; Figures 6A,B $)$, but there was no significant trend across the three grazing exclusion chronosequence treatments (Figure 6). In addition, the N:P ratio gradually decreased in L. chinensis stems and aboveground portions growing in grazing exclusion plots $(P<0.05$; Figure 6C). In contrast, leaf $\mathrm{N}: \mathrm{P}$ increased initially and then decreased with the increase of grazing exclusion time (Figure 6C). Finally, C:N and C:P were positively correlated with plant traits, but $\mathrm{N}: \mathrm{P}$ was negatively correlated with plant traits $(P<0.05$; Table 4$)$.
TABLE 4 | Relationships of plant size (PC axis 1) with C, N, and P ecological stoichiometry in leaves, stems, and aboveground portions in Leymus chinensis individuals.

\begin{tabular}{|c|c|c|c|c|c|c|}
\hline \multirow[t]{2}{*}{ Elements } & \multicolumn{2}{|c|}{ Leaf } & \multicolumn{2}{|c|}{ Stem } & \multicolumn{2}{|c|}{ Aboveground } \\
\hline & $r$ & $P$ & $r$ & $P$ & $r$ & $P$ \\
\hline $\mathrm{C}: \mathrm{N}$ & 0.63 & $<0.01$ & 0.72 & $<0.01$ & 0.69 & $<0.01$ \\
\hline$C: P$ & 0.31 & $<0.05$ & -0.21 & $>0.05$ & 0.17 & $>0.05$ \\
\hline$N: P$ & -0.38 & $<0.01$ & -0.81 & $<0.01$ & -0.80 & $<0.01$ \\
\hline
\end{tabular}

\section{DISCUSSION}

Morphological plasticity, which exists in various terrestrial plant species, is a comprehensive strategy to adapt to heterogeneous habitats. This strategy allows plants to effectively gain access to more resources (de Vries et al., 2016). Grazing affects natural pastures in the macro-scale performance of ecosystems and the plant function at the micro-scale in semi-arid regions (Sanjuán et al., 2017). Our results demonstrated that $L$. chinensis leaves and stems exponentially tended to be larger after grazing exclusion over time compared with plants in free-grazing conditions. This is consistent with the findings described in several previous studies (Deléglise et al., 2011; Wu et al., 2013). We detected a dramatic change (0.05-6.8) in the plasticity of different functional traits with the increase of grazing exclusion time. The sensitivity of stems was higher than that of leaves with the increase of grazing exclusion time, indicating that L. chinensis can exhibit rapid pant growth by promoting stem elongation. A previous study on leaf traits indicated that the strategies for stability and plant protection under grazing disturbance provides some indirect evidence for our findings (Jaurena et al., 2013).

In our study, individual L. chinensis leaf and stem mass accumulation exponentially increased during the peak-growth season with the increase of grazing exclusion time. This is consistent with results from previous studies conducted in a variety of grassland habitats (Courtois et al., 2004; Shrestha and Stahl, 2008). However, there was a slight decrease in biomass accumulation after long-term grazing exclusion (plot from 1979) compared to the medium-term plot (established in 1999). This may be related to the tradeoff between leaf and stem growth after long-term grazing exclusion (35-years in this study). Specifically, intraspecific and interspecific competition for light resources will be intensified in grazing exclusion habitats (Borer et al., 2014); therefore, plant stem elongation will be stimulated as a shade avoidance response to light limitations (Baldissera et al., 2016). Photoassimilates will be preferentially allocated to the stem to rapidly increase the plant individual height during the stem elongation process (Williamson et al., 2012), which may be the underlying mechanism for our finding that the leaf to stem mass ratio significantly decreases in the long-term grazing exclusion habitats.

We initially hypothesized that increased nutrient concentrations in plant tissues would support plant morphological plasticity in response to grazing exclusion, but this was not supported by our results that grazing exclusion significantly decreased $\mathrm{N}$ and $\mathrm{P}$ concentrations. Theoretically, 
this may be explained by three previously discussed hypotheses. First, the growth dilution hypothesis: if increased accumulation of shoot mass is more than the increase in nutrient acquisition under grazing exclusion, nutrient concentrations will decrease (Li et al., 2016b). Second, the decreasing metabolism hypothesis: decreased $\mathrm{N}$ and $\mathrm{P}$ concentrations might weaken the number and activity of photosynthetic enzymes and improve the photosynthetic rate when plants are grown under grazing exclusion conditions (Scogings et al., 2013). Third, the nutrient competition hypothesis: competition for soil nutrients under grazing exclusions became significantly more intense compared to grazed habitats, contributing to the decrease of nutrient concentrations ( $\mathrm{Lü}$ et al., 2015). In general, our finding that grazing exclusion significantly decreased $\mathrm{N}$ and $\mathrm{P}$ concentrations in L. chinensis is similar with previous studies on experimental grazing, mowing, elevated $\mathrm{CO}_{2}$, and drought, supported by the mechanisms discussed above (Fernando et al., 2014; Li et al., 2016b).

We observed a sharp decrease of $\mathrm{N}$ and $\mathrm{P}$ concentrations after grazing exclusion in the degraded pasture; however, only minor changes in $\mathrm{N}$ concentration and increases in $\mathrm{P}$ were detected across grazing exclusions established in 2005, 1999, and 1979. Therefore, the growth dilution hypothesis provides only a partial explanation for these findings. It is also likely associated with the drivers of the metabolism regulation hypothesis. In contrast, we found that $C$ concentrations in the three sampling positions rapidly increased after grazing exclusions. This is most likely related to greater photosynthetic function and an adequate supply of carbon assimilates in the grazing excluded pastures. This suggests that there was a tradeoff of $\mathrm{C}$ concentration with $\mathrm{N}$ and $\mathrm{P}$ concentrations, and it may provide new insight into plant nutrient strategies in response to grazing exclusion.

An interesting result was that leaf to stem ratios of $\mathrm{N}, \mathrm{P}$, and $\mathrm{C}$ accumulation were negatively correlated with plant size induced by grazing exclusion. We also found that the degrees of plasticity of L. chinensis individuals in stem traits were markedly higher than that in leaf traits under grazing exclusion. We speculate that there may be some theoretical correlation between nutrient allocation and leaf-stem allometry (Li et al., 2015a). Our SEM results demonstrated that the changes in N, $\mathrm{P}$, and $\mathrm{C}$ allocation induced by grazing exclusion were derived from leaf to stem ratios of biomass and nutrient concentration. A previous study has shown that light competition affects plant growth in restored grassland communities (Loydi et al., 2015). For example, shade avoidance can significantly promote the nutrient allocation and growth of plant stems (Heger, 2016). Hence, with the increase of grazing exclusion time, the increased stem nutrient allocation in response to light competition may explain the observed stimulation of stem elongation and biomass accumulation.

The C:P and C:N ratios of plant illustrate the $\mathrm{C}$ assimilation efficiency when absorbing one unit $\mathrm{N}$ and $\mathrm{P}$. In general, these ratios can be a predictive indicator of nitrogen- and phosphorususe efficiency in many ecosystems (Zhou et al., 2013). Increased nutrient use efficiency in plants is known to be an important strategy for adaptation to nutrient-poor habitats. Our finding that grazing exclusion increased $\mathrm{C}: \mathrm{N}$ and $\mathrm{C}: \mathrm{P}$ ratios and decreased $\mathrm{N}$ and $\mathrm{P}$ concentrations is not consistent with previous studies on soil nutrient enrichments (Feyisa et al., 2017; Wang T. et al., 2017), thus suggesting that soil nutrient changes induced by grazing exclusion are not the primary reason for changes in plant nutrient strategies. In addition, we found that grazing exclusion significantly increased the C:N and C:P ratios in leaves, stems, and the aboveground parts of L. chinensis individuals. This implies that changes in C:N and C:P ratios of plant tissues may be a temporary response to livestock grazing, which differs from the lag effect of plant morphology, community productivity, and soil features.

Nutrient limitation for grassland plants in a plant-herbivore interaction system has long been a controversial topic. The N:P ratio in ecological stoichiometry is often adopted to estimate nutrient limiting factors in plants across many ecosystems (Zhan et al., 2017). A previous study revealed that a $\mathrm{N}: \mathrm{P}$ ratio $>16$ indicates $\mathrm{P}$ limitation at a community level, while a N:P ratio $<14$ is indicative of $\mathrm{N}$ limitation (Bai et al., 2012). We found that $\mathrm{N}: \mathrm{P}$ in $L$. chinensis individuals was lower than the threshold of 14:1 for $\mathrm{N}$ limitation, and that $\mathrm{N}: \mathrm{P}$ gradually decreased with the increase of grazing exclusion time, especially in L. chinensis stems. This may be related to the increasing rapid growth and $\mathrm{N}$ requirements of stems with the increase of the duration of grazing exclusion.

Our findings have important implications for understanding the potential effects of grazing on plant traits and nutrient strategies in grassland regions, and for developing useful management practices to improve pasture productivity ( $\mathrm{Wu}$ et al., 2014). Theoretically, we provide new evidence for understanding the relationship between plant size and nutrients in grazing ecosystems. Practically, grazing-induced changes in individual plant size under increased human activity will dramatically affect pasture productivity, and the effects will be especially profound in the pastures in Inner Mongolia, China (Bai et al., 2012). Based on our findings that there were potentially $\mathrm{P}$ and $\mathrm{N}$ limitations of the dominated L. chinensis in freegrazing and grazing exclusion grasslands respectively, we suggest promoting pasture utilization reasonably and P-optimized management should be preferred in degraded grasslands, whereas $\mathrm{N}$-optimized management should be the primary measure to increase pasture productivity in grazing exclusion pastures.

\section{CONCLUSION}

We concluded that the increase of grazing exclusion time exponentially increased plant morphological traits, and nutrient concentrations and stoichiometry in the degraded pasture were also strongly impacted. There was a significant negative correlation between the degrees of plasticity and stability of various morphological traits. The patterns of biomass allocation of L. chinensis were significantly correlated with the increased duration of grazing exclusion, primarily determined by changes in stem traits. Phenotypic traits were negatively correlated with $\mathrm{N}$ and $\mathrm{P}$ concentrations, but they were positively correlated with $\mathrm{C}$ concentration. Further, we detected that there was a tradeoff 
between concentrations and the accumulation of $\mathrm{N}$ and $\mathrm{P}$, but coordinated variation of $\mathrm{C}$. We discovered that changes in $\mathrm{N}$, $\mathrm{P}$, and $\mathrm{C}$ allocation induced by grazing exclusion were derived from biomass partitioning and leaf to stem ratios of nutrient concentrations. In general, our findings suggest that there is a significant negative effect between plant sizes and nutrient traits under grazing exclusion.

\section{AUTHOR CONTRIBUTIONS}

ZL: wrote the paper and the data analysis. TB: designed the study. JD: carried out the experiments. GY, JS, and XL collected the data and data analysis.

\section{REFERENCES}

Abdalla, M., Hastings, A., Chadwick, D. R., Jones, D. L., Evans, C. D., Jones, M. B., et al. (2018). Critical review of the impacts of grazing intensity on soil organic carbon storage and other soil quality indicators in extensively managed grasslands. Agric. Ecosyst. Environ. 253, 62-81. doi: 10.1016/j.agee.2017.10.023

Armitage, H. F., Britton, A. J., Van Der Wal, R., and Woodin, S. J. (2012). Grazing exclusion and phosphorus addition as potential local management options for the restoration of alpine moss-sedge heath. Biol. Conserv. 153, 17-24. doi: 10.1016/j.biocon.2012.04.025

Bai, Y., Wu, J., Clark, C. M., Pan, Q., Zhang, L., Chen, S., et al. (2012). Grazing alters ecosystem functioning and $\mathrm{C}: \mathrm{N}$ : P stoichiometry of grasslands along a regional precipitation gradient. J. Appl. Ecol. 49, 1204-1215. doi: 10.1111/j.1365-2664. 2012.02205.x

Baldissera, T. C., Pontes, L. D. S., Giostri, A. F., Barro, R. S., Lustosa, S. B. C., De Moraes, A., et al. (2016). Sward structure and relationship between canopy height and light interception for tropical C4 grasses growing under trees. Crop Pasture Sci. 67, 1199-1207. doi: 10.1071/CP16067

Bennett, L., Judd, T., and Adams, M. (2003). Growth and nutrient content of perennial grasslands following burning in semi-arid, sub-tropical Australia. Plant Ecol. 164, 185-199. doi: 10.1023/A:1021253600712

Borer, E. T., Seabloom, E. W., Gruner, D. S., Harpole, W. S., Hillebrand, H., Lind, E. M., et al. (2014). Herbivores and nutrients control grassland plant diversity via light limitation. Nature 508, 517-520. doi: 10.1038/nature13144

Byrne, B. M. (2013). Structural Equation Modeling with AMOS: Basic Concepts, Applications, and Programming. Abingdon: Routledge.

Conant, R. T., and Paustian, K. (2002). Spatial variability of soil organic carbon in grasslands: implications for detecting change at different scales. Environ. Pollut. 116, S127-S135. doi: 10.1016/S0269-7491(01)00265-2

Courtois, D. R., Perryman, B. L., and Hussein, H. S. (2004). Vegetation change after 65 years of grazing and grazing exclusion. J. Range Manage. 157, 574-582. doi: 10.1016/j.scitotenv.2017.08.018

da Silveira Pontes, L., Louault, F., Carrère, P., Maire, V., Andueza, D., and Soussana, J.-F. (2010). The role of plant traits and their plasticity in the response of pasture grasses to nutrients and cutting frequency. Ann. Bot. 105, 957-965. doi: 10.1093/aob/mcq066

de Vries, F. T., Brown, C., and Stevens, C. J. (2016). Grassland species root response to drought: consequences for soil carbon and nitrogen availability. Plant Soil 409, 297-312. doi: 10.1007/s11104-016-2964-4

Deléglise, C., Loucougaray, G., and Alard, D. (2011). Spatial patterns of species and plant traits in response to 20 years of grazing exclusion in subalpine grassland communities. J. Veg. Sci. 22, 402-413. doi: 10.1111/j.1654-1103.2011. 01277.x

Deng, L., Shangguan, Z.-P., Wu, G.-L., and Chang, X.-F. (2017). Effects of grazing exclusion on carbon sequestration in China's grassland. Earth Sci. Rev. 173, 84-95. doi: 10.1016/j.earscirev.2017.08.008

Dostál, P., Fischer, M., and Prati, D. (2016). Phenotypic plasticity is a negative, though weak, predictor of the commonness of 105 grassland species. Glob. Ecol. Biogeogr. 25, 464-474. doi: 10.1111/geb.12429

\section{FUNDING}

This study was financially supported by the Natural Science Foundation of China (31702161), the China Agriculture Research System (CARS-34) and the Natural Science Foundation of Inner Mongolia (2017MS0379). The long-term site was maintained by the Inner Mongolia Grassland Ecosystem Research Station of the Chinese Academy of Sciences.

\section{ACKNOWLEDGMENTS}

We are grateful to the two reviewers for their constructive comments on this manuscript.

Eby, S., Agrawal, A., Majumder, S., Dobson, A. P., and Guttal, V. (2017). Alternative stable states and spatial indicators of critical slowing down along a spatial gradient in a savanna ecosystem. Glob. Ecol. Biogeogr. 26, 638-649. doi: 10.1111/ geb. 12570

Fernando, N., Panozzo, J., Tausz, M., Norton, R. M., Neumann, N., Fitzgerald, G. J., et al. (2014). Elevated $\mathrm{CO}_{2}$ alters grain quality of two bread wheat cultivars grown under different environmental conditions. Agric. Ecosyst. Environ. 185, 24-33. doi: 10.1016/j.agee.2013.11.023

Feyisa, K., Beyene, S., Angassa, A., Said, M. Y., De Leeuw, J., Abebe, A., et al. (2017). Effects of enclosure management on carbon sequestration, soil properties and vegetation attributes in East African rangelands. CATENA 159, 9-19. doi: 10.1016/j.catena.2017.08.002

Fort, F., Cruz, P., Catrice, O., Delbrut, A., Luzarreta, M., Stroia, C., et al. (2015). Root functional trait syndromes and plasticity drive the ability of grassland Fabaceae to tolerate water and phosphorus shortage. Environ. Exp. Bot. 110, 62-72. doi: 10.1016/j.envexpbot.2014.09.007

Han, J., Zhang, Y., Wang, C., Bai, W., Wang, Y., Han, G., et al. (2008). Rangeland degradation and restoration management in China. Rangeland J. 30, 233-239. doi: 10.1371/journal.pone.0132897

He, N., Wu, L., Wang, Y., and Han, X. (2009). Changes in carbon and nitrogen in soil particle-size fractions along a grassland restoration chronosequence in northern China. Geoderma 150, 302-308. doi: 10.1016/j.geoderma.2009.02.004

Heger, T. (2016). Light availability experienced in the field affects ability of following generations to respond to shading in an annual grassland plant. J. Ecol. 104, 1432-1440. doi: 10.1111/1365-2745.12607

Heyburn, J., Mckenzie, P., Crawley, M. J., and Fornara, D. A. (2017). Effects of grassland management on plant C:N:P stoichiometry: implications for soil element cycling and storage. Ecosphere 8:e01963. doi: 10.1002/ecs2.1963

Huang, L., Liang, Z., Suarez, D. L., Wang, Z., Ma, H., Wang, M., et al. (2015). Continuous nitrogen application differentially affects growth, yield, and nitrogen use efficiency of in two saline-Sodic soils of Northeastern China. Agron. J. 107, 314-322. doi: 10.2134/agronj14.0250

Jaurena, M., Lezama, F., and Cruz, P. (2013). Perennial grasses traits as functional markers of grazing intensity in basaltic grasslands of Uruguay. Chil. J. Agric. Res. 72, 541-549. doi: 10.4067/S0718-58392012000400013

Jing, Z., Cheng, J., Su, J., Bai, Y., and Jin, J. (2014). Changes in plant community composition and soil properties under 3-decade grazing exclusion in semiarid grassland. Ecol. Eng. 64, 171-178. doi: 10.1371/journal.pone.0026506

Laliberté, E., Shipley, B., Norton, D. A., and Scott, D. (2012). Which plant traits determine abundance under long-term shifts in soil resource availability and grazing intensity? J. Ecol. 100, 662-677. doi: 10.1111/j.1365-2745.2011.01947.x

Li, X., Hou, X., Ren, W., Baoyin, T., Liu, Z., Badgery, W., et al. (2016a). Long-term effects of mowing on plasticity and allometry of Leymus chinensis in a temperate semi-arid grassland, China. J. Arid Land 8, 899-909. doi: 10.1007/s40333-0160005-Z

Li, X., Liu, Z., Wang, Z., Wu, X., Li, X., Hu, J., et al. (2015a). Pathways of Leymus chinensis individual aboveground biomass decline in natural semiarid grassland induced by overgrazing: a study at the plant functional trait scale. PLoS One 10:e0124443. doi: 10.1371/journal.pone.0124443 
Li, X., Liu, Z.-Y., Ren, W.-B., Ding, Y., Ji, L., Guo, F.-H., et al. (2016b). Linking nutrient strategies with plant size along a grazing gradient: evidence from Leymus chinensis in a natural pasture. J. Integr. Agric. 15, 1132-1144. doi: 10.1016/S2095-3119(15)61171-6

Li, X., Wu, Z., Liu, Z., Hou, X., Badgery, W., Guo, H., et al. (2015b). Contrasting effects of long-term grazing and clipping on plant morphological plasticity: evidence from a rhizomatous grass. PLoS One 10:e0141055. doi: 10.1371/ journal.pone.0141055

Liu, G., and Han, J. (2008). Seedling establishment of wild and cultivated Leymus chinensis (Trin.) Tzvel. under different seeding depths. J. Arid Environ. 72, 279-284. doi: 10.1016/j.jaridenv.2007.06.008

Loydi, A., Donath, T. W., Otte, A., and Eckstein, R. L. (2015). Negative and positive interactions among plants: effects of competitors and litter on seedling emergence and growth of forest and grassland species. Plant Biol. 17, 667-675. doi: $10.1111 /$ plb.12287

Lü, X.-T., Freschet, G. T., Flynn, D. F. B., and Han, X.-G. (2012a). Plasticity in leaf and stem nutrient resorption proficiency potentially reinforces plant-soil feedbacks and microscale heterogeneity in a semi-arid grassland. J. Ecol. 100, 144-150. doi: 10.1111/j.1365-2745.2011.01881.x

Lü, X.-T., Freschet, G. T., Kazakou, E., Wang, Z.-W., Zhou, L.-S., and Han, X.-G. (2015). Contrasting responses in leaf nutrient-use strategies of two dominant grass species along a 30-yr temperate steppe grazing exclusion chronosequence. Plant Soil 387, 69-79. doi: 10.1007/s11104-014-2282-7

Lü, X.-T., Lü, F.-M., Zhou, L.-S., Han, X., and Han, X.-G. (2012b). Stoichiometric response of dominant grasses to fire and mowing in a semi-arid grassland. J. Arid Environ. 78, 154-160. doi: 10.1016/j.jaridenv.2011.11.008

Ma, L., Yuan, S., Guo, C., and Wang, R. (2014). Carbon and nitrogen dynamics of native Leymus chinensis grasslands along a $1000 \mathrm{~km}$ longitudinal precipitation gradient in northeastern China. Biogeosciences 11, 7097-7106. doi: 10.5194/bg11-7097-2014

Nicotra, A. B., Atkin, O. K., Bonser, S. P., Davidson, A. M., Finnegan, E. J., Mathesius, U., et al. (2010). Plant phenotypic plasticity in a changing climate. Trends Plant Sci. 15, 684-692. doi: 10.1016/j.tplants.2010.09.008

Odriozola, I., García-Baquero, G., Fortin, M.-J., Laskurain, N. A., and Aldezabal, A. (2017). Grazing exclusion unleashes competitive plant responses in Iberian Atlantic mountain grasslands. Appl. Veg. Sci. 20, 50-61. doi: 10.1111/avsc.12277

Olmo, M., Lopez-Iglesias, B., and Villar, R. (2014). Drought changes the structure and elemental composition of very fine roots in seedlings of ten woody tree species. Implications for a drier climate. Plant Soil 384, 113-129. doi: 10.1007/ s11104-014-2178-6

Ren, A., Wei, M., Yin, L., Wu, L., Zhou, Y., Li, X., et al. (2014). Benefits of a fungal endophyte in Leymus chinensis depend more on water than on nutrient availability. Environ. Exp. Bot. 108, 71-78. doi: 10.1016/j.envexpbot.2013.11.019

Ren, W., Hu, N., Hou, X., Zhang, J., Guo, H., Liu, Z., et al. (2017). Long-term overgrazing-induced memory decreases photosynthesis of clonal offspring in a perennial grassland plant. Front. Plant Sci. 8:419. doi: 10.3389/fpls.2017.00419

Sanjuán, Y., Arnáez, J., Beguería, S., Lana-Renault, N., Lasanta, T., GómezVillar, A., et al. (2017). Woody plant encroachment following grazing abandonment in the subalpine belt: a case study in northern Spain. Reg. Environ. Change 19, 1-13. doi: 10.1007/s10113-017-1245-y

Schönbach, P., Wan, H., Schiborra, A., Gierus, M., Bai, Y., Müller, K., et al. (2009). Short-term management and stocking rate effects of grazing sheep on herbage quality and productivity of Inner Mongolia steppe. Crop Pasture Sci. 60, 963-974. doi: 10.1071/CP09048

Scogings, P. F., Hjältén, J., and Skarpe, C. (2013). Does large herbivore removal affect secondary metabolites, nutrients and shoot length in woody species in semi-arid savannas? J. Arid Environ. 88, 4-8. doi: 10.1016/j.jaridenv.2012. 08.010

Shrestha, G., and Stahl, P. D. (2008). Carbon accumulation and storage in semi-arid sagebrush steppe: effects of long-term grazing exclusion. Agric. Ecosyst. Environ. 125, 173-181. doi: 10.1016/j.agee.2007.12.007

Silcock, J. L., and Fensham, R. J. (2013). Arid vegetation in disequilibrium with livestock grazing: evidence from long-term exclosures. Aust. Ecol. 38, 57-65. doi: 10.1111/j.1442-9993.2012.02374.x

Velthuis, M., Van Deelen, E., Van Donk, E., Zhang, P., and Bakker, E. S. (2017). Impact of temperature and nutrients on carbon: nutrient tissue stoichiometry of submerged aquatic plants: an experiment and meta-analysis. Front. Plant Sci. 8:655. doi: 10.3389/fpls.2017.00655

Wang, D., Du, J., Zhang, B., Ba, L., and Hodgkinson, K. C. (2017). Grazing intensity and phenotypic plasticity in the clonal grass Leymus chinensis. Rangeland Ecol. Manage. 70, 740-747. doi: 10.1016/j.rama.2017.06.011

Wang, T., Zhang, Z., Li, Z., and Li, P. (2017). Grazing management affects plant diversity and soil properties in a temperate steppe in northern China. CATENA 158, 141-147. doi: 10.1016/j.catena.2017.06.020

Williamson, M. M., Wilson, G. W., and Hartnett, D. C. (2012). Controls on bud activation and tiller initiation in $\mathrm{C} 3$ and $\mathrm{C} 4$ tallgrass prairie grasses: the role of light and nitrogen. Botany 90, 1221-1228. doi: 10.1139/b2012-091

Wu, J., Zhang, X., Shen, Z., Shi, P., Xu, X., and Li, X. (2013). Grazing-exclusion effects on aboveground biomass and water-use efficiency of alpine grasslands on the northern Tibetan Plateau. Rangeland Ecol. Manage. 66, 454-461. doi: 10.2111/REM-D-12-00051.1

Wu, X., Li, P., Jiang, C., Liu, P., He, J., and Hou, X. (2014). Climate changes during the past 31 years and their contribution to the changes in the productivity of rangeland vegetation in the Inner Mongolian typical steppe. Rangeland J. 36, 519-526.

Yang, Z., Baoyin, T., Minggagud, H., Sun, H., and Li, F. Y. (2017). Recovery succession drives the convergence, and grazing versus fencing drives the divergence of plant and soil N/P stoichiometry in a semiarid steppe of Inner Mongolia. Plant Soil 420, 303-314. doi: 10.1007/s11104-017-3404-9

Zhan, S., Wang, Y., Zhu, Z., Li, W., and Bai, Y. (2017). Nitrogen enrichment alters plant N: P stoichiometry and intensifies phosphorus limitation in a steppe ecosystem. Environ. Exp. Bot. 134, 21-32. doi: 10.1016/j.envexpbot.2016.10.014

Zheng, S., Ren, H., Li, W., and Lan, Z. (2012). Scale-dependent effects of grazing on plant C: N: P stoichiometry and linkages to ecosystem functioning in the Inner Mongolia grassland. PLoS One 7:e51750. doi: 10.1371/journal.pone.0051750

Zhou, Y.-C., Fan, J.-W., Harris, W., Zhong, H.-P., Zhang, W.-Y., and Cheng, X.-L. (2013). Relationships between C3 plant foliar carbon isotope composition and element contents of grassland species at high altitudes on the QinghaiTibet Plateau, China. PLoS One 8:e60794. doi: 10.1371/journal.pone.006 0794

Conflict of Interest Statement: The authors declare that the research was conducted in the absence of any commercial or financial relationships that could be construed as a potential conflict of interest.

Copyright (c) 2018 Liu, Baoyin, Duan, Yang, Sun and Li. This is an open-access article distributed under the terms of the Creative Commons Attribution License (CC BY). The use, distribution or reproduction in other forums is permitted, provided the original author(s) and the copyright owner are credited and that the original publication in this journal is cited, in accordance with accepted academic practice. No use, distribution or reproduction is permitted which does not comply with these terms. 